\title{
Factors affecting autologous peripheral blood hematopoietic stem cell collections by large-volume leukapheresis: a single center experience
}

\author{
Fatores que afetam a coleta de células-tronco hematopoiéticas do sangue periférico por \\ leucaférese de grande volume: experiência de um único centro
}

\begin{abstract}
Araci Massami Sakashita ${ }^{1}$, Andrea Tiemi Kondo ${ }^{1}$, Andreza Alice Feitosa Ribeiro $^{2}$, Andrea Neri Folchini Cipolletta ${ }^{1}$, Monica Vilela Colesanti ${ }^{1}$, Nelson Hamerschlak ${ }^{3}$, Jose Mauro Kutner ${ }^{4}$
\end{abstract}

\begin{abstract}
Objective: To evaluate factors affecting peripheral blood hematopoietic stem cell yield in patients undergoing large-volume leukapheresis for autologous peripheral blood stem cell collection. Methods: Data from 304 consecutive autologous peripheral blood stem cell donors mobilized with hematopoietic growth factor (usually G-CSF), associated or not with chemotherapy, at Hospital Israelita Albert Einstein between February 1999 and June 2010 were retrospectively analyzed. The objective was to obtain at least $2 \times 10^{6}$ $\mathrm{CD} 34+$ cells $/ \mathrm{kg}$ of body weight. Pre-mobilization factors analyzed included patient's age, gender and diagnosis. Post mobilization parameters evaluated were pre-apheresis peripheral white blood cell count, immature circulating cell count, mononuclear cell count, peripheral blood CD34 + cell count, platelet count, and hemoglobin level. The effect of pre and post-mobilization factors on hematopoietic stem cell collection yield was investigated using logistic regression analysis (univariate and multivariate approaches). Results: Premobilization factors correlating to poor $\mathrm{CD} 34+$ cell yield in univariate analysis were acute myeloid leukemia $(p=0.017)$ and other hematological diseases $(p=0.023)$. Significant post-mobilization factors included peripheral blood immature circulating cells $(p=$ $0.001)$, granulocytes $(p=0.002)$, hemoglobin level $(p=0.016)$, and CD34+ cell concentration $(p<0.001)$ in the first harvesting day. However, according to multivariate analysis, peripheral blood CD34+ cell content $(p<0.001)$ was the only independent factor that significantly correlated to poor hematopoietic stem cell yield. Conclusion: In this study, peripheral blood CD34 + cell concentration was the only factor significantly correlated to yield in patients submitted to for autologous collection.
\end{abstract}

Keywords: Hematopoietic stem cells; Mobilization; Leukapheresis; Blood specimen collection/methods; Transplantation, autologous.

\section{RESUMO}

Objetivo: Avaliar fatores que afetam o rendimento da coleta em pacientes submetidos à leucaférese de grande volume para obtenção de células-tronco hematopoiéticas do sangue periférico para autotransplante. Métodos: Análise retrospectiva de 304 doadores de células-tronco hematopoiéticas de sangue periférico para autotransplante submetidos à mobilização com fator de crescimento hematopoiético (geralmente G-CSF), associado ou não à quimioterapia, no Hospital Israelita Albert Einstein de Fevereiro de 1999 a Junho de 2010. 0 objetivo da coleta foi obter pelo menos $2 \times 10^{6} \mathrm{CD} 34+$ células $/ \mathrm{kg}$ peso. 0 s fatores pré-mobilização incluíam idade, sexo e diagnóstico do paciente. Os parâmetros pós-mobilização avaliados foram contagem de leucócitos, células imaturas, células mononucleares e células $\mathrm{CD} 34+$, plaquetas e nível de hemoglobina no sangue periférico. 0 efeito desses fatores no rendimento da coleta de CTH foi investigado por meio de regressão logística (análise univariada e multivariada). Resultados: A análise univariada revelou os seguintes fatores pré-mobilização estatisticamente significantes: diagnóstico de leucemia mieloide aguda $(p=0,017)$ e outras doenças hematológicas $(p=0,023)$, células imaturas circulantes $(p=0,001)$, granulócitos $(p=0,002)$, nível de hemoglobina $(p=0,016)$ e contagem de células CD34+ ( $p<0,001)$ no primeiro dia de coleta. Entretanto, só a contagem de células $\mathrm{CD} 34+$ no sangue periférico manteve-se associada de forma significante ao rendimento ruim da coleta de células-

\footnotetext{
Study carried out at Hospital Israelita Albert Einstein - HIAE, São Paulo (SP), Brazil.

${ }^{1}$ Hemotherapy, Hospital Israelita Albert Einstein - HIAE - São Paulo (SP), Brazil.

${ }^{2}$ Blood Bank, Hospital Israelita Albert Einstein - HIAE - São Paulo (SP), Brazil; Hematology and Bone Marrow Transplantation, Hospital Israelita Albert Einstein - HIAE - São Paulo, Brazil.

${ }^{3}$ Hematology and Bone Marrow Transplantation, Hospital Israelita Albert Einstein - HIAE - São Paulo, Brazil.

${ }^{4}$ Blood Bank, Hospital Israelita Albert Einstein - HIAE - São Paulo (SP), Brazil.

Corresponding author: Araci Massami Sakashita - Banco de Sangue do Hospital Israelita Albert Einstein - Avenida Albert Einstein, 627, $4^{\circ}$ andar - Morumbi - CEP 05651-901 - São Paulo (SP), Brasil Tel.: (11) 2151-0444 - E-mail: aracims@einstein.br

Received on: Dec 1, 2010 - Accepted on: Apr 5, 2011

The authors declare there is no conflict of interest.
} 
tronco hematopoiéticas na análise multivariada. Conclusão: Neste estudo, a contagem de células CD34+ no sangue periférico foi 0 único fator significantemente associado ao rendimento da coleta de células-tronco hematopoiéticas com leucaférese de grande volume para autotransplante.

Descritores: Células-tronco hematopoéticas; Mobilização; Leucaférese; Coleta de amostras sanguíneas/métodos; Transplante autólogo

\section{INTRODUCTION}

High-dose chemotherapy, together with hematopoietic stem cell (HSC) harvest, has been successfully used in the management of a variety of malignant and nonmalignant diseases ${ }^{(1)}$. Mobilized peripheral blood stem cells (PBSC) became the preferred source for autologous transplantation ${ }^{(2)}$. The advantages of PBSC compared with bone marrow stem cells include a faster hematopoietic recovery and enhanced immune reconstitution with a relatively easy collection procedure $^{(3)}$.

Rapid and sustained engraftment depends on the number of HSC infused. A significant correlation between the total number of infused CD34+ cells and successful hematological recovery was previously reported, indicating that the collection of adequate number of these cells is a key factor for safe engraftment ${ }^{(4)}$. There is evidence to support that reliable and sustained engraftment occur in patients receiving at least $2 \times 10^{6}$ $\mathrm{CD} 34+/ \mathrm{kg}$ of body weigh ${ }^{(5,6)}$.

Classical PBSC mobilization strategies include the administration of granulocyte colony-stimulating factor (G-CSF) alone or in combination with myelosuppressive chemotherapy or other cytokines ${ }^{(2,7-}$ 10). Autologous PBSC are usually collected by leukapheresis during hematologic recovery phase from the administration of the mobilizing agents. However, peripheral blood (PB) CD34+ cell concentration kinetics varies among individual patients and according to chemotherapy regimen ${ }^{(7)}$. The timing for collection after mobilization is crucial to maximize PBSC yield. Suggested predictive factors for starting leukapheresis have included PB leukocyte count, mononuclear cell count, platelet count, and the PB CD34+ cell count ${ }^{(6,7,11)}$. PB CD34+ cell concentration on the first day of harvest $\geq 10$ to $20 \times 10^{3} / \mathrm{mL}$ is widely used as a surrogate marker for starting PBSC collections ${ }^{(12)}$.

The appropriate regimen for PBSC collections has not yet been established. Standard or normalvolume leukapheresis (NVL) procedure usually processes 2.5 to 3 times the patient's total blood volume (TBV), whereas in large-volume leukapheresis (LVL), 3 to 6 times the patient's TBV is processed. LVL was reported as a safe and useful strategy to maximize autologous CD34 + cell yield especially in patients with low PB CD34+ cell concentration $^{(13-18)}$.

Unfortunately, from 5 to $40 \%$ of patients undergoing autologous PBSC collection failed to achieve the minimum dose of $2 \times 10^{6} \mathrm{CD} 34+$ cell/ $\mathrm{kg}$ body weight considering a single mobilization attempt. These patients are called "poor mobilizers". The identification of factors affecting PBSC yield has been the objective of several studies. Patients' age and gender, interval from the last chemotherapy treatment, bone marrow involvement, diagnosis and disease status, prior radiation, number and type of previous chemotherapy regimens, and fever of unknown origin were associated with poor PBSC mobilization. However, there is still no specific factor to identify a poor mobilizer ${ }^{(7,19.20)}$.

\section{OBJECTIVE}

To evaluate factors affecting PBSCyield in a retrospective analysis of patients undergoing LVL for autologous PBSC collection.

\section{METHODS}

Data from 304 consecutive autologous PBSC donors mobilized with G-CSF associated or not with chemotherapy at Hospital Israelita Albert Einstein (HIAE) between February 1999 and June 2010 were retrospectively analyzed. Mobilization of HSC included three different regimens: $4 \mathrm{~g} / \mathrm{m}^{2}$ of cyclophosphamide associated with G-CSF (Granulokine, Roche, Reinach, Switzerland) $10 \mathrm{mg} / \mathrm{kg}$ body weight; G-CSF $10 \mathrm{mg} /$ $\mathrm{kg}$ body weight; or disease-specific chemotherapy, followed by daily stimulation with G-CSF $10 \mathrm{mg} / \mathrm{kg}$ body weight.

Complete blood cell count was evaluated daily after mobilization with chemotherapy. PB CD34+ cell count was determined when white blood cell count (WBC) had risen to greater than 1.000 cells $/ \mathrm{mL}$. Peripheral blood WBC and CD34+ cell counts were determined on the fourth day of G-CSF administration for patients mobilized with this growth factor alone. PBSC collections were started with PB CD34+ cell counts greater than 10 cells $/ \mathrm{mL}$.

Leukapheresis for PBSC collections were performed with a continuous flow blood cell separator (Spectra, Caridian BCT, Lakewood, CO, USA) using a semi-automated mononuclear cell (MNC) or an automated auto-PBSC protocol. Daily PBSC collections were performed in order to reach an 
individual targeted yield of $\geq 2 \times 10^{6} \mathrm{CD} 34+$ cells $/ \mathrm{kg}$ body weight. LVL processing four times the patient's TBV was employed with the aim of maximizing CD34+ yield per procedure. A central venous catheter was inserted when the patient's peripheral venous access was considered poor to sustain an adequate inlet flow rate during apheresis. For extracorporeal anticoagulation we used the ACD-A, at a ratio of $1: 13$ to $1: 16$. All patients received prophylactic intravenous calcium and potassium infusions during leukapheresis. The cell products collected were frozen in dimethylsulfoxide (DMSO) and stored in liquid nitrogen or in a mechanical freezer.

$\mathrm{CD} 34+$ cells were counted in the PB and the leukapheresis product by flow cytometry, as previously described ${ }^{(21)}$. Briefly, MNC were stained with phycoerythrin-conjugated anti-CD34+ (antiHPCA 2) and counterstained with fluorescein isothiocyanate-conjugated anti-CD45. Cells were analyzed by fluorescein-activated sorting (Coulter ${ }^{\circledR}$ Epics XL-MCL ${ }^{\mathrm{TM}}$ Flow Cytometer, Beckman Coulter, Brea, CA, USA). For each sample, we analyzed 100.000 events.

The collection goal was to obtain at least $2 \times 10^{6}$ CD34 cells/kg body weight. Therefore, successful collection was defined when this target was reached within three consecutive LVL. Pre-mobilization factors analyzed included patients' age, gender, and diagnosis. Post-mobilization parameters evaluated were pre-apheresis $\mathrm{PB}$ WBC, immature circulating cells, MNC cells, PB CD34+ cells, platelet count, and hemoglobin level.

All data were analyzed with the software Statistical Package for the Social Sciences (SPSS, Chicago, IL, USA). The effects of pre- and post-mobilization factors on HSC collection efficiency were investigated using logistic regression analyses (univariate and multivariate approaches). Variables with a $p$ value $<0.10$ in univariate analysis were included in the multivariate model. A p value $<0.05$ was considered statistically significant.

\section{RESULTS}

A total of 304 patients were submitted to 312 mobilization attempts during the study period. Patients' demographics are depicted on table 1. LVL was performed in 283 adults and in 21 pediatric patients with a mean age of 46 years (range: 3 to 73 years). The lymphoma group included 95 non-Hodgkin's and 19 relapsed Hodgkin's disease patients. Multiple sclerosis was the most prevalent diagnosis among autoimmune disease patients. Other onco-hematological diseases included acute leukemia other than acute myeloid leukemia (AML), chronic leukemia, and myelodisplastic syndrome.

\begin{tabular}{lc}
\multicolumn{2}{l}{ Table 1. Clinical characteristics of autologous peripheral blood stem cell donors } \\
\hline Number of patients & 304 \\
Age (years) & $46 \pm 16(3-73)$ \\
Sex & \\
Male & $176(58 \%)$ \\
Female & $128(42 \%)$ \\
Diagnosis & \\
Lymphoma & $114(38 \%)$ \\
Multiple myeloma & $68(22 \%)$ \\
Auto immune disease & $37(12 \%)$ \\
Acute myeloid leukemia & $33(11 \%)$ \\
Solid tumor & $31(10 \%)$ \\
Other hematological diseases & $21(07 \%)$ \\
Weight $(\mathrm{kg})^{*}$ & $73 \pm 96(13-143)$ \\
Total blood volume (mL) & $4.578 \pm 1.023(927-7.714)$ \\
\hline
\end{tabular}

${ }^{*}$ Mean \pm standard deviation (range).

A total of $573 \mathrm{LVL}$ were performed with a mean of 2 (range: 1 to 8 ) leukaphereses per patient. The targeted HSC yield ( $\geq 2 \times 10^{6} \mathrm{CD} 34+$ cells/kg body weight) was obtained in 275/312 (88\%) mobilization attempts. Therefore, poor HSC yield occurred in 37/312 (12\%) of these mobilization cycles. The incidence of poor HSC yield according to patient's diagnosis is depicted on table 2.

Table 2. Incidence of poor CD34+ yield ( $<2 \times 10^{6} \mathrm{CD} 34+$ cells $/ \mathrm{kg}$ body weight) in 312 mobilization attempts for autologous PBSC collections

\begin{tabular}{lcc}
\hline \multirow{2}{*}{ Disease } & \multicolumn{2}{c}{ CD34+ cells/kg body weight } \\
\cline { 2 - 3 } & $\mathbf{2} \mathbf{2 \times 1 \mathbf { 1 0 } ^ { \mathbf { 6 } }}$ & $<\mathbf{2 \times 1 \mathbf { 1 0 } ^ { \mathbf { 6 } }}$ \\
\hline Lymphoma & $106(92 \%)$ & $9(8 \%)$ \\
Multiple myeloma & $67(92 \%)$ & $6(8 \%)$ \\
Auto immune disease & $36(97 \%)$ & $1(3 \%)$ \\
Acute myeloid leukemia & $24(73 \%)$ & $9(27 \%)$ \\
Solid tumor & $25(81 \%)$ & $6(19 \%)$ \\
Other hematological diseases & $17(74 \%)$ & $6(26 \%)$ \\
\hline
\end{tabular}

Factors correlated to poor CD34+ cell yield in univariate analysis are listed in table 3. Premobilization factors significantly affecting CD34+ yield were AML $(p=0.017)$ and other hematological diseases $(p=0.023)$. Significant post-mobilization factors included PB immature circulating cells $(\mathrm{p}=$ $0.001)$, granulocytes $(\mathrm{p}=0.002)$, hemoglobin level $(\mathrm{p}$ $=0.016)$, and CD34+ cell concentration $(\mathrm{p}<0.001)$ in the first day of harvest. However, according to the multivariate analysis, PB CD34+ cell content $(\mathrm{p}<$ 0.001 ) was the only independent factor significantly correlated to unsuccessful HSC yield (Table 4). 
Table 3. Factors associated with poor CD34 + cell yield in univariate analysis

\begin{tabular}{lccc}
\hline Variable & $\mathbf{O R}$ & $\mathbf{9 5 \%} \mathbf{C l}$ & $\mathbf{p}$ value \\
\hline Patient & & & \\
Age & 0.999 & $(0.978 ; 1.020)$ & 0.899 \\
$\quad$ Female gender & 0.834 & $(0.412 ; 1.691)$ & 0.615 \\
$\begin{array}{l}\text { Diagnosis } \\
\text { Lymphoma }\end{array}$ & 3.057 & $(0.374 ; 24.968)$ & 0.184 \\
Multiple myeloma & 3.224 & $(0.374 ; 27.826)$ & 0.287 \\
Acute myeloid leukemia & 13.500 & $(1.605 ; 113.552)$ & $0.017^{*}$ \\
Solid tumor & 8.640 & $(0.989 ; 76.251)$ & 0.052 \\
Other hematological diseases & 12.706 & $(1.416 ; 114.004)$ & $0.023^{*}$ \\
Pre-apheresis data & & & \\
PB white blood cells & 0.999 & $(0.981 ; 1.017)$ & 0.890 \\
PB immature cells & 0.839 & $(0.758 ; 0.928)$ & $0.001^{*}$ \\
PB granulocyte cells & 1.051 & $(1.019 ; 1.084)$ & $0.002^{*}$ \\
PB mononuclear cells & 0.983 & $(0.955 ; 1.013)$ & 0.274 \\
PB platelet count & 0.999 & $(0.995 ; 1.003)$ & 0.734 \\
PB hemoglobin level & 1.261 & $(1.045 ; 1.521)$ & $0.016^{*}$ \\
PB CD34+ cells & 0.836 & $(0.978 ; 1.020)$ & $<0.001^{*}$ \\
\hline
\end{tabular}

${ }^{*} \mathrm{~A} p$ value $<0.05$ was considered statistically significant.

OR: Odds ratio; 95\%Cl: 95\% confidence interval; PB: peripheral blood.

\begin{tabular}{lccc}
\multicolumn{4}{l}{ Table 4. Factors associated with poor CD34+ cell yield in multivariate analysis } \\
\hline Variable & $\mathbf{O R}$ & $\mathbf{9 5} \% \mathbf{C l}$ & $\mathbf{p}$ value \\
\hline Diagnosis & & & \\
Acute myeloid leukemia & 0.688 & $(0.053 ; 9.020)$ & 0.776 \\
Solid tumor & 0.543 & $(0.037 ; 8.058)$ & 0.657 \\
Other hematological diseases & 0.396 & $(0.026 ; 6.100)$ & 0.506 \\
Pre-apheresis data & & & \\
PB immature cells & 0.998 & $(0.872 ; 1.142)$ & 0.981 \\
PB granulocyte cells & 1.038 & $(0.984 ; 1.096)$ & 0.172 \\
PB hemoglobin level & 1.240 & $(1.946 ; 1.626)$ & 0.119 \\
PB CD34+ cells & 0.831 & $(0.769 ; 0.897)$ & $<0.001^{*}$ \\
\hline
\end{tabular}

*A p-value $<0.05$ was considered statistically significant

OR: Odds ratio; $95 \% \mathrm{Cl}$ : $95 \%$ confidence interval; PB: peripheral blood

\section{DISCUSSION}

HSC can be mobilized into the circulation by G-CSF, chemotherapy or both. Factors influencing HSC yield in a harvest have been extensively studied and are not completely understood. Variables reported to be associated with a poor yield included older age, certain disorders, high number and long duration of preceding chemotherapy events, the presence of marrow infiltrating disease, previous radiation, low pre-mobilization platelet count, short intervals from last chemotherapy cycle to mobilization, low pre-mobilization bone marrow CFU-GM levels, inadequate chemo-priming regimens, and/or low dose G-CSF(7). However, it is still difficult to draw a definite conclusion from these studies owing to the heterogeneity in the patient population in terms of their different disease characteristics ${ }^{(22)}$.

In this study, $88 \%$ of patients were able to reach the targeted HSC yield. This result is similar to the recent report from Wuchter et al. ${ }^{(23)}$. The patient age effect on HSC yield was evaluated in numerous studies with contradictory results ${ }^{(4,7,24)}$. Patient age and gender did not affect CD34+ cell yield in our study. The same findings were described by Wuchter et al. ${ }^{(23)}$. In contrast, age less than 38 years old and male gender were associated with a good HSC yield in healthy volunteer HSC donors ${ }^{(7)}$.

The role of diagnosis in patients failing HSC mobilization had also been reported. Acute leukemia was correlated to a poor HSC yield compared to other hematological malignancies ${ }^{(2,4,25)}$. Our study found that both AML and other hematological diseases affected negatively HSC yield in univariate analysis. A possible explanation could be the fact that the latter group included many patients with relapsed or refractory diseases. These patients might have received more chemotherapy cycles before HSC mobilization, a known factor which negatively affects HSC yield ${ }^{(23)}$. However, these disorders were not significant in multivariate analysis.

Post-mobilization factors affecting HSC yield already reported include $\mathrm{PB}$ immature myeloid circulating cells, granulocytes, and $\mathrm{PB} \mathrm{C} 34+$ cell concentration in the first day of harvest ${ }^{(7,16)}$. In our study, immature circulating cells, PB granulocytes count, hemoglobin level, and CD34 + cell concentration were found significantly correlated to HSC yield in univariate analysis. However, this correlation was not significant in multivariate analysis except for $\mathrm{PB}$ $\mathrm{CD} 34+$ cell concentration ${ }^{(11)}$. A high predictive value of PB CD34 + cell concentration and the yield of these cells in the apheresis product have been reported ${ }^{(11,26)}$.

The limitations of this retrospective study include sample heterogeneity, disease status and different mobilization regimens. Another issue is the lack of information about the total number of chemotherapy cycles and the agents used before mobilization. Prolonged chemotherapy treatment and alkylating agents have been reported as predictive factors associated with poor HSC yields ${ }^{(8,19,22-24)}$.

\section{CONCLUSION}

In this study PB CD34+ cell concentration was the only factor significantly correlated to HSC yields in patients submitted to LVL for autologous PBSC collection.

\section{ACKNOWLEDGMENTS}

We thank Angela Tavares Paes and Elivane da Silva Victor for helping with the statistical analysis. 


\section{REFERENCES}

1. Gratwohl A, Baldomero H, Frauendorfer K, Rocha V, Apperley J, Niederwieser D; Joint Accreditation Committee of the International Society for Cellular Therapy (ISCT); European Group for Blood and Marrow Transplantation EBMT (JACIE). The EBMT activity survey 2006 on hematopoietic stem cell transplantation: focus on the use of cord blood products. Bone Marrow Transplant. 2008;41(8):687-705.

2. Fruehauf $S$, Seggewiss R. It's moving day: factors affecting peripheral blood stem cell mobilization and strategies for improvement [corrected]. $\mathrm{Br} \mathrm{J}$ Haematol. 2003;122(3):360-75.

3. Liu JH, Chen CC, Bai LY, Chao SC, Chang MS, Lin JS. Predictors for successful mobilization of peripheral blood progenitor cells with ESHAP + G-CSF in patients with pretreated non-Hodgkin's lymphoma. J Chin Med Assoc. 2008;71(6):279-85.

4. Pastore D, Specchia G, Mestice A, Liso A, Pannunzio A, Carluccio P, et al. Good and poor CD34+ cells mobilization in acute leukemia: analysis of factors affecting the yield of progenitor cells. Bone Marrow Transplant. 2004;33(11):1083-7.

5. Takeyama K, Ohto H. PBSC mobilization. Transfus Apher Sci. 2004;31(3):233-43.

6. Pusic I, Jiang SY, Landua S, Uy GL, Rettig MP, Cashen AF, et al. Impact of mobilization and remobilization strategies on achieving sufficient stem cell yields for autologous transplantation. Biol Blood Marrow Transplant. 2008;14(9):1045-56.

7. Ikeda K, Kozuka T, Harada M. Factors for PBPC collection efficiency and collection predictors. Transfus Apher Sci. 2004;31(3):245-59.

8. Milone G, Leotta S, Indelicato F, Mercurio S, Moschetti G, Di Raimondo F, et al. G-CSF alone vs cyclophosphamide plus G-CSF in PBPC mobilization of patients with lymphoma: results depend on degree of previous pretreatment. Bone Marrow Transplant. 2003;31(9):747-54.

9. Kessinger A, Sharp JG. The whys and hows of hematopoietic progenitor and stem cell mobilization. Bone Marrow Transplant. 2003;31(5):319-29.

10. Greinix HT, Worel N. New agents for mobilizing peripheral blood stem cells. Transfus Apher Sci. 2009;41(1):67-71.

11. Ford CD, Chan KJ, Reilly WF, Petersen FB. An evaluation of predictive factors for CD34 + cell harvest yields from patients mobilized with chemotherapy and growth factors. Transfusion. 2003;43(5):622-5.

12. Gasová Z, Marinov I, Vodvárková S, Böhmová M, Bhuyian-Ludvíková Z. PBPC collection techniques: standard versus large volume leukapheresis (LVL) in donors and in patients. Transfus Apher Sci. 2005;32(2):167-76.

13. Abrahamsen JF, Stamnesfet S, Liseth K, Hervig T, Bruserud O. Large-volume leukapheresis yields more viable CD34+ cells and colony-forming units than normal-volume leukapheresis, especially in patients who mobilize low numbers of CD34+ cells. Transfusion. 2005;45(2):248-53.

14. Reddy RL. Mobilization and collection of peripheral blood progenitor cells for transplantation. Transfus Apher Sci. 2005;32(1):63-72.
15. Cassens U, Barth IM, Baumann C, Fischer RJ, Kienast J, Vormoor J, et al. Factors affecting the efficacy of peripheral blood progenitor cells collections by large-volume leukaphereses with standardized processing volumes. Transfusion. 2004;44(11):1593-602.

16. Sarkodee-Adoo C, Taran I, Guo C, Buadi F, Murthy R, Cox E, et al. Influence of preapheresis clinical factors on the efficiency of CD34+ cell collection by large-volume apheresis. Bone Marrow Transplant. 2003;31(10):851-5.

17. Cassens U, Ostkamp-Ostermann P, van der Werf N, Garritsen H, Ostermann H, Sibrowski W. Volume-dependent collection of peripheral blood progenitor cells during large-volume leukapheresis for patients with solid tumours and haematological malignancies. Transfus Med. 1999;9(4):31120.

18. Fontana S, Groebli R, Leibundgut K, Pabst T, Zwicky C, Taleghani BM. Progenitor cell recruitment during individualized high-flow, very-large-volume apheresis for autologous transplantation improves collection efficiency. Transfusion. 2006;46(8):1408-16.

19. Perseghin P, Terruzzi E, Dassi M, Baldini V, Parma M, Coluccia P, et al. Management of poor peripheral blood stem cell mobilization: incidence, predictive factors, alternative strategies and outcome. A retrospective analysis on 2177 patients from three major Italian institutions. Transfus Apher Sci. 2009;41(1):33-7.

20. Ford CD, Green W, Warenski S, Petersen FB. Effect of prior chemotherapy on hematopoietic stem cell mobilization. Bone Marrow Transplant. 2004;33(9):901-5.

21. Sutherland DR, Anderson L, Keeney M, Nayar R, Chin-Yee I. The ISHAGE guidelines for $\mathrm{CD} 34+$ cell determination by flow cytometry. International Society of Hematotherapy and Graft Engineering. J Hematother. 1996;5(3):21326.

22. Liu JH, Chen CC, Bai LY, Chao SC, Chang MS, Lin JS. Predictors for successful mobilization of peripheral blood progenitor cells with ESHAP + G-CSF in patients with pretreated non-Hodgkin's lymphoma. J Chin Med Assoc.2008;71 (6):27985.

23. Wuchter P, Ran D, Bruckner T, Schmitt T, Witzens-Harig M, Neben K, et al. Poor mobilization of hematopoietic stem cells-definitions, incidence, risk factors, and impact on outcome of autologous transplantation. Biol Blood Marrow Transplant. 2010;16(4):490-9.

24. Morris CL, Siegel E, Barlogie B, Cottler-Fox M, Lin P, Fassas A, et al. Mobilization of CD34 + cells in elderly patients ( $>/=70$ years) with multiple myeloma: influence of age, prior therapy, platelet count and mobilization regimen. $\mathrm{Br} J$ Haematol. 2003;120(3):413-23.

25. Koenigsmann M, Jentsch-Ullrich K, Mohren M, Becker E, Heim M, Franke A. The role of diagnosis in patients failing peripheral blood progenitor cell mobilization. Transfusion. 2004:44(5):777-84.

26. Nowrousian MR, Waschke S, Bojko P, Welt A, Schuett P, Ebeling P, et al. Impact of chemotherapy regimen and hematopoietic growth factor on mobilization and collection of peripheral blood stem cells in cancer patients. Ann Oncol. 2003;14 Suppl 1:i29-36. 